\title{
Western blot analysis of gonococcal serogrouping reagents
}

\author{
C G COPLEY AND S I EGGLESTONE \\ From the Gonococcus Reference Unit, Public Health Laboratory Service, Bristol
}

SUMMARY The W class antisera used in the coagglutination method of serogrouping Neisseria gonorrhoeae were anlaysed using sodium dodecyl sulphate polyacrylamide gel electrophoresis and western blot transfers. All were found to contain antibodies to the homologous protein II as well as antibodies to protein I group antigens. Examination of local isolates showed that some strains owed their reaction with coagglutination reagents to epitopes on their protein II not their protein I. How this may lead to difficulties when using coagglutination patterns to subdivide the $\mathrm{W}$ groups is discussed.

\section{Introduction}

The coagglutination method of Sandstrom and Danielsson is probably the easiest and most popular method of serotyping gonococci. ${ }^{1}$ It explains the antigenic structure of the gonococcal outer membrane in terms of three classes of antigens: W, J, and M. The W class antigens have been correlated with protein I antigens. ${ }^{2}$ The $J$ class antigens are thought to be present on protein II. $^{3}$ The $\mathbf{M}$ class antigens are thought to be lipopolysaccharide in nature. ${ }^{1}$ The antigenic instability of protein $\mathrm{II}^{4}$ makes $\mathrm{J}$ class antigens unsuitable as the basis for an epidemiological typing scheme. Furthermore, the $M$ class antigens have been found to be unstable during natural transmission. ${ }^{5}$ We have therefore concentrated on the W class, or protein $\mathbf{I}$, antigens as the basis for typing.

The $\mathrm{W}$ class antisera are prepared by selective cross absorption of hyperimmune rabbit sera against major outer membrane protein (MOMP) reference strains. ${ }^{6}$ They may be used to subdivide gonococci into two large groups: WI and WII/III. ${ }^{1}$ More than one reagent is needed to cover each group, which indicates that antigenic differences occur within the large groups. The pattern of reaction with individual $W$ class reagents has been used to subdivide the two large groups. ${ }^{7}$ When studying the stability of typing markers in vivo (unpublished observations) $)^{58}$ we have noted that, though $\mathrm{W}$ class serology is stable for the two major groups, changes in the patterns of reaction within these two groups can occur after natural transmission.

Address for reprints: Dr C G Copley, Coralab Research, Huntingdon Road Laboratories, Cambridge CB3 ODJ

Accepted for publication 5 June 1986
According to the antigenic structure proposed by Sandstrom and Danielsson, ${ }^{1}$ the absorption protocol used to prepare $\mathrm{W}$ class antisera will result in some of the reagents containing unwanted antibodies against other components of the outer membrane (additional factors). To define further the composition of the typing sera and to assess the effect of the additional factors on testing local isolates we decided to examine antisera and organisms by a combination of sodium dodecyl sulphate polyacrylamide gel electrophoresis (SDS-PAGE) and western blot transfers.

\section{Materials and methods}

STRAINS OF NEISSERIA GONORRHOEA

MOMP reference strains A-1, B-2, C-3, D-4, E-5, F-6, N-10, S-12, U-14, and V-15 were kindly provided by Dr D Danielsson. ${ }^{6}$ Test strains were selected from our collection of strains isolated from patients attending sexually transmitted disease clinics in Avon during 1982 and 1983.

\section{PREPARATION OF OUTER MEMBRANE VESICLES}

Gonococci were suspended to about $10 \%$ (wet weight/ volume) in $0.2 \mathrm{~mol} / \mathrm{l}$ lithium acetate and $10 \mathrm{mmol} / \mathrm{l}$ disodium ethylenediamine tetra-acetate, and were then blended for 15 minutes at room temperature. Whole organisms were removed by two centrifugation steps: $10000 \times g$ for 10 minutes and $20000 \times g$ for 20 minutes. The clear supernate was then centrifuged at $130000 \times g$ for 90 minutes to collect the outer membranes. They were suspended in $0.3 \mathrm{ml}$ of solubilising buffer (glycerol $5 \mathrm{ml}, 2$-mercaptoethanol $2.5 \mathrm{ml}$, sodium dodecyl sulphate $1.5 \mathrm{~g}$, bromophenol blue $0.005 \mathrm{~g}$, TRIS base $0.38 \mathrm{~g}$, and water to $50 \mathrm{ml}$ ) per gram wet weight of starting material. The outer membrances were solubilised at $100^{\circ} \mathrm{C}$ for five 
minutes and at $37^{\circ} \mathrm{C}$ for 30 minutes.

PREPARATION OF W CLASS ANTISERA

Hyperimmune rabbit antisera were prepared against MOMP reference strains D-4, E-5, V-15, N-10, S-12, U-14, and F-6 by the following method. New Zealand white rabbits were immunised intradermally with formalised whole organisms mixed with an equal volume of Freund's complete adjuvant. Two weeks later this was repeated but incomplete adjuvant was used. A further two weeks later $0.1 \mathrm{ml}$ suspension of formalised whole organisms was injected intraveneously, followed by $0.25 \mathrm{ml}$ three days later, $0.5 \mathrm{ml}$ four days later, and finally $1.0 \mathrm{ml}$ three days later. The rabbits were bled a week after the last injections.

These sera were then absorbed with MOMP reference strains as indicated in table I. Absorbants

TABLE I Preparation of $W$ class antisera (sera raised against major outer membrane protein (MOMP) reference strains were selectively absorbed with other MOMP strains to produce three WI and four WII/III antisera).

\begin{tabular}{llll}
\hline $\begin{array}{l}\text { W class } \\
\text { antisera }\end{array}$ & Antiserum & Absorbed with & $\begin{array}{l}\text { Additional } \\
\text { factors }\end{array}$ \\
\hline WI & D-4 & A-1 and C-3 & J/4 \\
WI & E-5 & N-10 and C-3 & None \\
WI & V-15 & N-10 and C-3 & $\mathrm{J} / 4$ and M/g \\
WII/III & N-10 & D-4 and E-5 & None \\
WII/III & S-12 & A-1 and E-5 & $\mathrm{J} / 12$ and M/e \\
WII/III & U-14 & A-1 and B-2 & $\mathrm{J} / 14$ \\
WII/III & F-6 & B-2 and U-14 & $\mathrm{J} / 9$ and J/6 \\
\hline
\end{tabular}

were prepared by suspending $1 \mathrm{~g}$ (wet weight) of the appropriate organism in $4 \mathrm{ml}$ distilled water and sonicating for $5 \times 30$ seconds. A volume of $1 \mathrm{ml}$ of antisera was then mixed with the necessary absorbants, incubated at $37^{\circ} \mathrm{C}$ for three hours, and then at $4^{\circ} \mathrm{C}$ overnight. The absorbed antisera (W class antisera) were recovered by centrifugation at $20000 \times g$ for 30 minutes. They were then dispensed in $0.2 \mathrm{ml}$ aliquots and stored at $-20^{\circ} \mathrm{C}$. The $\mathrm{W}$ class antisera were used to prepare $\mathrm{W}$ class coagglutination reagents as described previously ${ }^{5}$ and in western blot experiments described below.

\section{SDS-PAGE AND WESTERN BLOT TRANSFERS}

Solubilised outer membranes $(8 \mu \mathrm{l})$ and molecular weight markers (Dalton Mark VII-L, Sigma) were separated using the discontinuous buffer system of Laemmli ${ }^{9}$ with a $4.5 \%$ stacking gel and a $12.5 \%$ separating gel. Gels were electrophoresed for one hour at $10 \mathrm{~mA}$, then at $20 \mathrm{~mA}$ until the tracking dye reached the end. At this point the lanes containing the molecular weight markers were cut off and stained with Coomassie brilliant blue. The separated components of the outer membrane were electrophoretically transferred to nitrocellulose paper according to the method of Burnette. ${ }^{10}$ After transfer the nitrocellulose sheet was incubated for one hour at ambient temperature in $5 \%$ bovine serum albumin in washing buffer $(51$ Dulbecco A phosphate buffered saline, $25 \mathrm{ml}$ polysorbate (Tween) $80,1.85 \mathrm{~g}$ disodium ethylenediamine tetraacetate, and $102.25 \mathrm{~g}$ sodium chloride, adjusted to pH 7.2), followed by incubation for one hour in $5 \%$ bovine serum albumin in washing buffer containing $0 \cdot 1$ $\mathrm{ml}$ of $\mathrm{W}$ class antiserum. The nitrocellulose was then washed for 40 minutes with four changes of washing buffer, followed by incubation in $5 \%$ bovine serum albumin in washing buffer containing $0.05 \mathrm{ml}$ goat anti-rabbit IgG horseradish peroxidase conjugate (Sigma). The blot was then washed as before, before adding the substrate $(8 \mathrm{mg}$ diaminobenzidine and $10 \mu \mathrm{l}$ hydrogen peroxide in $20 \mathrm{ml}$ McIlvaines citratephosphate buffer, $\mathrm{pH} 5 \cdot 2$ ). After five minutes the stained nitrocellulose was washed extensively under the tap. The position of the outer membrane proteins was assessed by comparison with the position of the molecular mass markers. In addition protein II could be identified by its apparent increase in molecular mass when solubilised at $100^{\circ} \mathrm{C}$ rather than $37^{\circ} \mathrm{C}$.

\section{AUXOTYPING}

Auxotyping was performed on local isolates as described previously. ${ }^{1}$ We examined requirements for proline ( $\left.\mathrm{Pro}^{-}\right)$, arginine $\left(\mathrm{Arg}^{-}\right)$, hypoxanthine $\left(\mathrm{Hyp}^{-}\right)$, uracil ( $\left.\mathrm{Ura}^{-}\right)$, and arginine requirement not satisfied by ornithine $\left(\mathrm{Arg}^{\circ}\right)$.

\section{SEROGROUPING}

Serogrouping was performed using W class coagglutination reagents as described previously. ${ }^{5}$

\section{Results}

Table II shows the results of auxotyping, W class serology, and susceptibility to penicillin of the local isolates used in this study. Strains requiring arginine, hypoxanthine, and uracil for growth reacted with the WI reagents, all other local isolates reacted with WII/ III reagents.

In all the western blot experiments described here the strongest reaction was seen with the protein I or protein II, or both, of test strains. Weaker reactions with other undefined components of the outer membrane of some strains, however, were detected with some W class antisera.

Table III shows the results of western blot experiments, in which W class antisera were tested against the separated components of the MOMP reference strains used in their production. All W class antisera contained antibodies against the protein $I$ and the protein II of the immunising strain. Furthermore, in all 
TABLE II Auxotype, W class serology, and minimum inhibitory concentrations (MICs) of penicillin for the local isolates used in this study

\begin{tabular}{|c|c|c|c|c|c|c|c|c|c|}
\hline \multirow{3}{*}{$\begin{array}{l}\text { Strain } \\
\text { No }\end{array}$} & \multirow[b]{3}{*}{ Auxotype } & \multicolumn{7}{|c|}{$W$ class coagglutination results* } & \multirow{3}{*}{$\begin{array}{l}M I C \\
(m g /))\end{array}$} \\
\hline & & \multicolumn{3}{|c|}{ WI reagents } & \multicolumn{4}{|c|}{ WII/II reagents } & \\
\hline & & $\overline{D-4}$ & $E-5$ & $V-15$ & $\overline{N-10}$ & $S-12$ & $U-14$ & $F-6$ & \\
\hline 1 & $\mathrm{Arg}^{-} \mathrm{Hyp}^{-} \mathrm{Ura}^{-}$ & - & $3+$ & $2+$ & - & - & - & - & 0.02 \\
\hline 2 & $\mathrm{Arg}^{-} \mathrm{Hyp}^{-} \mathrm{Ura}^{-}$ & - & $3+$ & $2+$ & - & - & - & - & 0.04 \\
\hline 3 & Pro & - & - & - & $3+$ & $2+$ & $3+$ & - & 0.16 \\
\hline 4 & Pro ${ }^{-}$ & - & - & - & $3+$ & $3+$ & $3+$ & - & 0.04 \\
\hline $5 \dagger$ & Non-requiring & - & - & - & $3+$ & $2+$ & $3+$ & - & $0 \cdot 32$ \\
\hline $6 \dagger$ & Non requiring & - & - & - & - & $2+$ & $3+$ & - & 0.32 \\
\hline 7 & Non-requiring & - & - & - & - & - & - & $3+$ & 0.16 \\
\hline 8 & $\mathrm{Arg}^{-}$ & - & - & - & $3+$ & - & $3+$ & - & 0.16 \\
\hline 9 & $\mathrm{Arg}^{-}$ & - & - & - & $3+$ & - & $3+$ & - & 0.32 \\
\hline 10 & $\mathrm{Arg}^{\circ} \mathrm{Hyp}^{-} \mathrm{Ura}^{-}$ & - & - & - & $2+$ & - & $3+$ & - & 0.04 \\
\hline 11 & Pro $^{-} \mathrm{Arg}^{\circ} \mathrm{Ura}^{-}$ & - & - & - & $1+$ & $1+$ & $3+$ & - & 0.32 \\
\hline
\end{tabular}

* W class reagents designated by the immunising strain used in their production (see table $\mathrm{I}$ ); $-=$ negative, $+=$ positive results . † Strains 5 and 6 were isolated from sexual partners.

$\mathrm{Arg}^{-}=$requiring arginine $; \mathrm{Hyp}^{-}=$requiring hypoxanthine $; \mathrm{Ura}^{-}=$requiring uracil $; \mathrm{Pro}^{-}=$requiring proline $; \mathrm{Arg}^{\circ}=$ with arginine requirement not satisfied by ornithine; non requiring $=$ prototrophic.

instances the anti-protein II activity appeared to be stronger than the anti-protein I activity.

Particular W class antisera reacted with the protein I of several MOMP reference strains of the same W group, but usually reacted with only the protein II of the immunising strain. The antisera prepared from anti $D-4$ and anti-V-15, however, reacted with the protein I and the protein II of both D-4 and V-15 (fig 1), thus reinforcing the view of Sandstrom and

TABLE III Western blot analysis of the reaction of $W$ class antisera with major outer membrane protein (MOMP) reference strains and local isolates. Strong reactions were detected between some $W$ class antisera and the protein I or protein II, or both, of particular test strains.

\begin{tabular}{lll}
\hline $\begin{array}{l}\text { W class } \\
\text { antisera }\end{array}$ & $\begin{array}{l}\text { Strains reacting in } \\
\text { protein I position }\end{array}$ & $\begin{array}{l}\text { Strains reacting in } \\
\text { protein II position }\end{array}$ \\
\hline E-5 & D-4, E-5, V-15 & E-5 \\
& 1,2 & - \\
D-4 & D-4, V-15 & D-4, V-15 \\
& - & - \\
V-15 & D-4, V-15 & D-4, V-15 \\
& - & 1,2 \\
N-10 & N-10, S-12, U-14 & N-10 (2 bands $)$ \\
& $4,8,9,10$ & $3,4,5,9$ \\
S-12 & N-10, S-12 & S-12 \\
& $3,5,6$ & $3,5,6$ \\
U-14 & N-10, U-14 & U-14 \\
& $3,4,5,6,8,9,10$ & $4,8,9$ \\
F-6 & A-1, F-6 & F-6 (2 bands $)$ \\
& 7 & - \\
\hline
\end{tabular}

$-=$ No test strains reacted with named $\mathbf{W}$ class antiserum in this position.
Danielsson ${ }^{1}$ that these two $\mathrm{W}$ class antisera share the same contaminating $\mathrm{J}$ factor. The protein II of local $\mathrm{Arg}^{-} \mathrm{Hyp}^{-} \mathrm{Ura}^{-}$strains described in table II reacted with absorbed anti-V-15 but not absorbed anti-D-4. The protein I of these strains reacted with the $\mathrm{W}$ class antiserum prepared from anti-E-5.

None of the other $W$ class antisera examined reacted with the protein II of heterologous MOMP reference strains, but they did react with the protein II of a range of local isolates (table III). Strains 5 and 6 , which were isolated from sexual partners, were the same auxotype and had the same susceptibility to penicillin. Though they were of the same $W$ group, they showed a different pattern of reaction in the coagglutination test. Strain 5 reacted with absorbed anti-N-10 but strain 6 did not. Figure 2 shows that the reaction between absorbed anti-N-10 and strain 5 was solely due to antigens on its protein II molecule. Thus the apparent antigenic difference between strains 5 and 6 was due to variation in their protein II molecules and not their protein $I$.

The protein I and protein II of a given strain reacted only with one class of absorbed antisera, which suggests that particular antigenic structures of protein II are exclusive to a specific $W$ group.

Though the $\mathrm{Pro}^{-} \mathrm{Arg}^{\circ} \mathrm{Ura}^{-}$strain reacted strongly with absorbed anti-U-14 in the coagglutination test, no reaction was detected by western blot analysis.

\section{Discussion}

The western blot experiments described here showed that all the $\mathrm{W}$ class antisera reacted strongly with both 


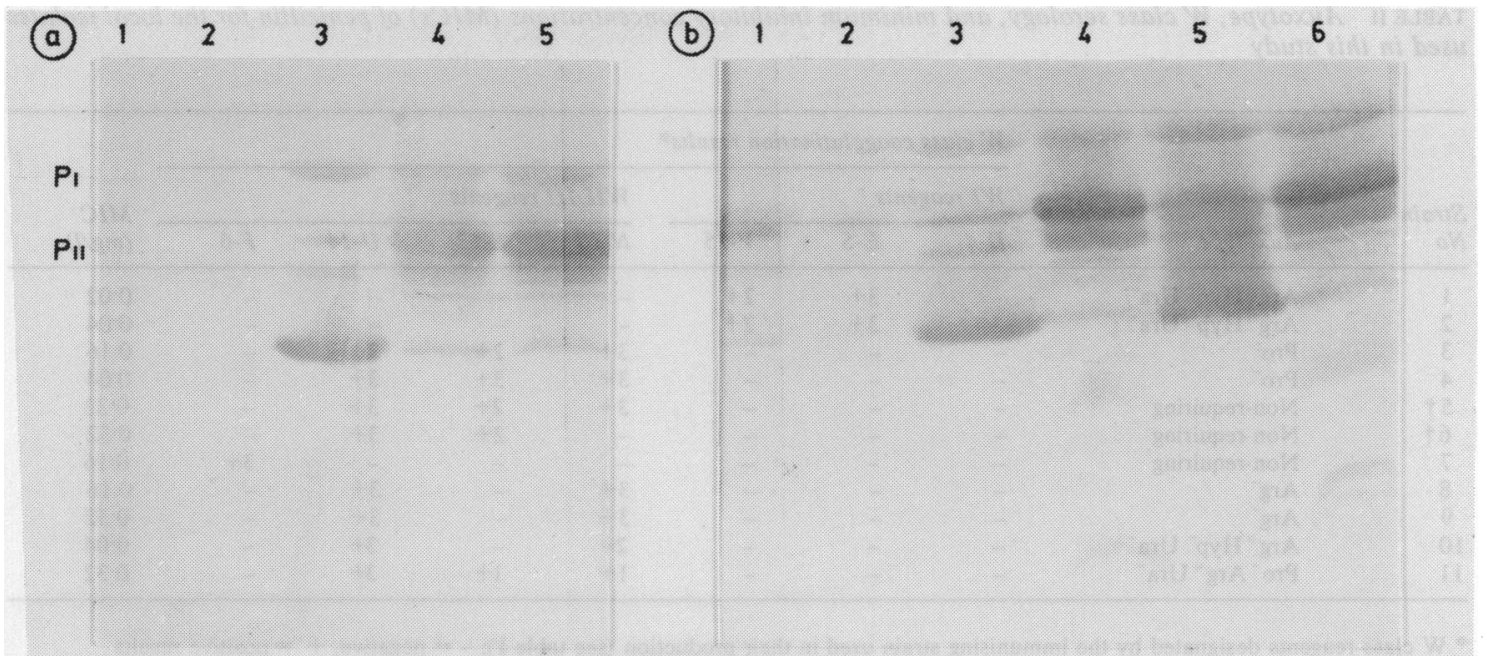

FIG 1 Reaction of WI reagents prepared from anti-D-4 and anti-V-15. (a): lanes 1 and 2 - local $\mathrm{Arg}^{-} \mathrm{Hyp}^{-} \mathrm{Ura}^{-}$strains; lanes 3 and $4-D-4$ solubilised at $37^{\circ} \mathrm{C}$ and $100^{\circ} \mathrm{C}$; lane $5-\mathrm{V}-15$ solubilised at $100^{\circ} \mathrm{C}$. Reacted with absorbed anti-D-4. (b): lanes 1 and $2-$ local $\mathrm{Arg}^{-} \mathrm{Hyp}^{-}$Ura strains; lanes 3 and $4-\mathrm{D}-4$ solubilised at $100^{\circ} \mathrm{C}$ and $37^{\circ} \mathrm{C}$; lanes 5 and $6-V-15$ solubilised at $100^{\circ} \mathrm{C}$ and $37^{\circ} \mathrm{C}$. Reacted with absorbed anti-V-15. (P = protein. See table II for meanings of other abbreviations.)

the protein I and the protein II of the immunising MOMP reference strain. Most $\mathrm{W}$ class antisera reacted with the protein I, but not the protein II, of other MOMP strains in the same $\mathrm{W}$ group. This reinforces the view that $\mathrm{W}$ class antigens are on the protein I and the $\mathbf{J}$ class antigens are on the protein II.

The $W$ class antisera prepared from anti-D-4 and anti-V -15 reacted with the protein $I$ and protein II of both D-4 and V-15, which supports the view of Sandstrom and Danielsson that these strains share $J$ class antigens. ${ }^{1}$ The protein II of local $\mathrm{Arg}^{-} \mathrm{Hyp}^{-} \mathrm{Ura}^{-}$ strains, however, reacted with absorbed anti-V-15 but not absorbed anti-D-4, which indicates that, though the protein II of these two strains share antigens, they are not identical.

The $\mathrm{W}$ class reagents prepared from anti-E-5 and anti-N-10 were thought to be free from $J$ class antibodies, ${ }^{1}$ but western blot experiments showed that both these antisera were active against the protein II of the respective immunising strain.

We have not found that the protein II of WI type organisms react with WII/III antisera, or vice versa. Thus it appears that the range of variable epitopes expressed on protein II is unique to a particular W group, even though protein II molecules show considerable structural homology.$^{12}$ In practical terms this means that, though they all contain unwanted antibodies against protein II epitopes, W class antisera 
can be used to divide clinical isolates of $\mathrm{Ngonorrhoeae}$ into two distinct groups.

The fact that more than one reagent is needed to cover each W group indicates that antigenic differences occur within the two major groups, as well as between them. The results presented here support this: strains $4,8,9$, and 10 having protein I epitopes in common with MOMP strains $\mathrm{N}-10$ and $\mathrm{U}-14$, but not with S-12 and F-6; strains 3, 5, and 6 sharing epitopes with S-12 and U-14, but not with N-10 and F-6; and strain 7 sharing epitopes with F-6, but not with $\mathrm{N}-10$, S-12, or U-14. Buchanan and Hildebrandt divided gonococci into nine serovars, ${ }^{13}$ but their groups were not mutually exclusive and a given strain may react with more than one reagent. Thus further division of the two major $W$ groups may rely on a formula approach.

The different patterns of reaction obtained with WII/III reagents have been used to subdivide this group. We feel that, as all our W class antisera showed a strong reaction with protein II and as gonococci are known to change their protein II composition in vitro ${ }^{4}$ and in vivo,${ }^{14}$ it may be inadvisable to rely on these reagents to subdivide the large W groups. Furthermore, we have shown that the different coagglutination patterns produced by two strains that were isolated from sexual partners were due to differences in their protein II not their protein I.

The antisera described here show stronger antiprotein II activity than anti-protein I activity, which would make the resulting coagglutination reagents sensitive to changes in protein II. Differences in the ratio of anti-protein I and anti-protein II antibodies are known to occur during the course of immunisation and in different animals. ${ }^{15}$ If the antisera produced by other workers ${ }^{7}$ contained less anti-protein II activity than anti protein I activity, then their reagents would be less sensitive to changes in protein II, and would thus be more suitable for subdividing the large $\mathrm{W}$ groups.

As the anti protein I monoclonal antibodies described by Tam et $a l^{16}$ become more widely available, the problems of subdividing gonococci serologically with absorbed polyclonal antisera should diminish.

Though good correlation was found between the results obtained using $\mathrm{W}$ class antisera in western blot experiments and using the same antisera in coagglutinatioin experiments, certain limitations of each method should be considered. The harsh treatment of the specimens before SDS-PAGE may denature irreversibly some epitopes that are recognised in the coagglutination test. Presumably this explains why the local $\mathrm{Pro}^{-} \mathrm{Arg}^{\circ} \mathrm{Ura}^{-}$strain reacted strongly with absorbed anti-U-14 in the coagglutination test but failed to show any reaction with the same antiserum in western blot experiments.Conversely the separation of outer membrane components by SDSPAGE may expose some antigens that are buried and inaccessible on the whole organism used in the coagglutination test.

We thank Dr A E Jephcott, Director of the Bristol Public Health Laboratory, for granting permission and facilities to carry out this work.

\section{References}

1. Sandstrom E, Danielsson D. Serology of Neisseria gonorrhoeae. Classification by co-agglutination. Acta Pathol Microbiol Scand [B] 1980;88:27-38.

2. Sandstrom EG, Knapp JS, Buchanan TB. Serology of Neisseria gonorrhoeae: W-antigen serogrouping by co-agglutination and Protein I serotyping by enzyme-linked immunosorbent assay both detect Protein I antigens. Infect Immun 1982;35:229-39.

3. Danielsson D, Sandstrom E. Serology of Neisseria gonorrhoeae. Demonstration by co-agglutination of antigenic differences associated with colour /opacity variants. Acta Pathol Microbiol Scand [B] 1980;88:39-46.

4. Lambden PR, Heckels JE. Outer membrane protein composition and colonial morphology of Neisseria gonorrhoeae strain P9. FEMS Microbiology Letters 1979;5:263-5.

5. Copley CG, Chiswell CP, Egglestone SI. Neisseria gonorrhoeae: stability of typing markers after natural transmission. British Journal of Venereal Diseases 1983;59:23741.

6. Johnston KH, Holmes KK, Gotschlich EC. The serological classification of Neisseria gonorrhoeae. J Exp Med 1976; 143:741-58.

7. Danielsson D, Bygdeman S, Kallings I, Sandstrom E. Epidemiology of gonorrhoea: serogroup, antibiotic susceptibility and auxotype patterns of consecutive gonococcal isolates from ten different areas of Sweden. Scand J Infect Dis 1983;15:33-42.

8. Copley CG, Gough KR, Egglestone SI. Epidemiological studies on Neisseria gonorrhoeae isolated in the United Kingdom. European Journal of Epidemiology 1985;1:16671.

9. Laemmli UK. Cleavage of structural proteins during the assembly of the head of bacteriophage T4. Nature 1970; 277:680-5.

10. Burnette WN. "Western Blotting": electrophoretic transfer of proteins from sodium dodecyl sulphate-polyacrylamide gels to unmodified nitrocellulose and radiographic detection with antibody and radio-iodinated Protein A. Anal Biochem 1981;112:195-201.

11. Copley CG, Egglestone SI. Auxotyping of Neisseria gonorrhoeae isolated in the United Kingdom.J Med Microbiol 1983;16:295-302.

12. Swanson J. ${ }^{125}$ I-labelled peptide mapping of some heat modifiable proteins of the gonococcal outer membrane. Infect Immun 1980;28:54-64.

13. Buchanan TM, Hildebrandt JF. Antigen specific serotyping of Neisseria gonorrhoeae: characterisation based upon principal outer membrane protein. Infect Immun 1981;35:985-94.

14. James JF, Swanson J. Studies on gonococcus infection XIII. Occurrence of color/opacity colonial variants in clinical cultures. Infect Immun 1978;19:332-40.

15. Swanson J. Surface exposed protein antigens of the gonococcal outer membrane. Infect Immun 1981;34:804-16.

16. Tam MR, Buchanan TM, Sandstrom EG, et al. Serological classification of Neisseria gonorrhoeae with monoclonal antibodies. Infect Immun 1982;36:1042-53. 